\title{
Response of Onion Crop to Foliar Application by Amino Acids, Yeast extract and Boron in Upper Egypt
}

\author{
Abdel-Rahim, G.H. ${ }^{1}$; A.A. Gamie ${ }^{2}$; M.S.S. Al-Bassuny ${ }^{1}$ and M.A.A. Abd Allah ${ }^{1}$ \\ ${ }^{1}$ Vegetable Sciences, Azhar University, (Assiut Branch). \\ ${ }^{2}$ Vegetable Sciences, Shandweel Agric. Res. Station ARC.
}

Received on: $3 / 3 / 2019$

Accepted for publication on: 11/3/2019

\section{Abstract}

Two field experiments were investigated in two successive seasons of 2016/2017 and 2017/2018 in sand loam soil of private farm in El-Usayrat village El-Monshaa City, Sohag Governorate, Egypt, to study the response of onion plants (cultivar Giza 6 mohassan) to foliar application of amino acids ( $1 \mathrm{gm} / \mathrm{l})$ from a compound contains $23.68 \%$ Free amino acids), yeast extract (5gm yeast/l) and boron $(5 \mathrm{~cm} / \mathrm{l})$ from compound contains $15 \%$ boron). Results showed that onion plant significantly affected by foliar application of bio-fertilizers (amino acid \& yeast) and boron. Foliar application of yeast extract + boron gave the maximum vegetative growth of onion plant including plant height and neck diameter. While, bulb yields was affected by foliar application of amino acid + boron. Results concluded that foliar application by amino acid + boron (T5) increased total yield by $(52.24 \%$ \& $50.15 \%)$, marketable yield by $(65.13 \%$ \& 63.54) and yield quality compared to control treatment in both seasons. Foliar application of (T5) tended to reduce culls yield, double bulbs (\%) and bolting bulbs (\%) in comparison to the control (T1) in the $1^{\text {st }}$ and $2^{\text {nd }}$ seasons, respectively. Storage period indicated that the minimum values of weight losses of onion (\%) were obtained from application of boron (T4) after 60, 120 and 180 days from storing in both seasons. Nutrient concentration in onion bulbs reveal that ( $\mathrm{N}, \mathrm{P}$ and $\mathrm{K}$ concentration) strongly responded to the foliar application of $\mathrm{T} 5$, while, boron concentration of onion bulbs responded to foliar application of boron (T4).

Keywords: onion, amino acids, boron, vegetative growth, nutrient concentration.

\section{Introduction}

Onion (Allium cepa, L.) is biennial crop. Onion is considered one of the principal field crops grown in Egypt. Moreover, beside its importance for local consumption, it has great potentiality as export commodity to some European and Arabic markets. Egypt is the seventh largest onion producer on a global level and onions are the third most important product in the country after oranges and potatoes. According to the latest Agricultural Export Council data (2017). Egypt produced 1.75 million tons of the red (1.6 million) and golden (580 thousand) varieties. 476 thousand tons were exported abroad, mainly to the EU, Arab countries, Asian countries and Russia. As for 2018, Egypt is expecting to produce 2 million tons with the objective of exporting 600 thousand tons of them after the new agreements stipulated by the government with China, Australia and South Africa. There is no doubt that mineral fertilizers are essential in most cropping systems if maximum yields are to be realized. Therefore, utilization of bio and mi- 
cro-nutrients in crops in order to sustain agricultural production and support soil fertility and healthy plant growth. In this context, the use of active natural compounds (amino acid $\&$ yeast extract) has been receiving increasing attention. According to Sarojnee et al. (2009) amino acids can improve fertilizer assimilation, increase uptake of nutrients and water, enhance the photosynthetic rate and dry matter partitioning, and hence increase yield and quality. Tugnoli and Bettini (2003) concluded that use of amino acids as foliar spraying makes it overcome the nutritional and environmental deficiencies that arise during the crop growth. Many authors reported that, the foliar application of amino acids can enhance plant growth, fruit yield and improve its quality in cucumber (Kandil et al., 2013). Yeast as a natural source of cytokinins-stimulates cell division and enlargement as well as the synthesis and enlargement as well as the synthesis of protein, nucleic acid and chlorophyll (Fathy and Farid, 1996). Hence, the objective of this investigation was to study the response of onion plants of variety Giza 6 mohassan to foliar application of amino acids, yeast extract and boron.

\section{Material and Methods}

Two field experiments were carried out at the private farm in ElUsayrat village El-Monshaa City, Sohag Governorate, Egypt, to study the response of onion plants to foliar application of amino acids, yeast extract and boron during two successive seasons of 2016/2017 and 2017/2018. Where the soil was clay loam. Seeds of onion cvs. Giza 6 mohassan was planted in the nursery at the $15^{\text {th }}$ Sep- tember 2016 and 2017 seasons, respectively. All agricultural processing for seedling production were followed as conventional method. Seedling was transplanted in the field after 45 days. The experimental plots were randomly assigned in a randomized complete block design with three replicates.

Treatments of foliar application were arranged as following:

T1. Control (water)

T2. Spraying amino acid

T3. Spraying yeast extract

T4. Control + boron $(\mathrm{T} 1+\mathrm{B})$

T5. Spraying amino acid + boron $(\mathrm{T} 2+\mathrm{B})$

T6. Spraying yeast extract + boron $(\mathrm{T} 3+\mathrm{B})$

Seedlings of the cultivar Giza 6 mohassan were transplanted at the first day of November in the $1^{\text {st }}$ and the $2^{\text {nd }}$ seasons. Plot area was $10.5 \mathrm{~m}^{2}$ $(1 / 400$ fed $\overline{\bar{j}}$ Mineral fertilizations were applied as recommended $(90 \mathrm{Kg}$ nitrogen, $45 \mathrm{Kg}$ phosphorous and 36 $\mathrm{Kg}$ potassium). Phosphorous fertilizer was applied in the form of super phosphate $\left(\begin{array}{lll}15 \% & \mathrm{P}_{2} \mathrm{O}_{5}\end{array}\right)$ during soil preparation. Nitrogen was applied in the form of ammonium nitrate $(33.5 \% \mathrm{~N})$ after one, two month from planting. Potassium fertilizer was added in the form of potassium sulphate $\left(48 \% \mathrm{~K}_{2} \mathrm{O}\right)$ after 2 month from cultivation. Foliar application treatments (amino-acid \& yeast extract) and boron was sprayed after 45, 60 and 75 days from planting in each season. Amino acid compound containing $23.68 \%$ free amino acids was sprayed at a rate of $(1 \mathrm{gm} / 1$.$) . Yeast$ was extracted and sprayed at a rate of (5 gm/1.). Boron compound contain- 
ing $15 \%$ boron was sprayed at a rate of $(5 \mathrm{~cm} / \mathrm{l}$.)

The experiments site was prepared using the conventional method. Soil samples were collected in both seasons from a depth of $60 \mathrm{~cm}$ prior to land preparation, dried for analysis. Analysis was carried out according Jackson (1973). Some physical and chemical properties of the experimental soil are shown in Table (1). Normal cultural practiced of growing onion including fertilization and irrigation was followed as recommended.
After harvestings, one hundred bulbs of randomly onion taken after curing as a representative sample from each plot and stored under room condition in both seasons during storage period in order to calculate the percentage of total weight losses at 60,120 and 180 days according to the following equation of Wills et al. (1982):

Weight loss $\%=$ Initial weight weight after storage/ initial weigh $\mathrm{X}$ 100

Table 1. Some physical and chemical properties of the experimental soil.

\begin{tabular}{|l|c|c|}
\hline \multicolumn{1}{|c|}{ Soil Analysis } & Season 2016/17 & Season 2017/18 \\
\hline Soil texture & Clay loam & Clay loam \\
\hline EC 1:5 (dS m -1) & 0.292 & 0.354 \\
\hline pH 1:5 & 8.12 & 8.22 \\
\hline Organic matter (\%) & 0.87 & 1.07 \\
\hline CaCO3 $\mathbf{3} \%)$ & 3.46 & 4.25 \\
\hline Total N (\%) & 0.141 & 0.146 \\
\hline Available P ppm & 15.00 & 17.00 \\
\hline Exchangeable K m. eq/100 g soil & 0.22 & 0.35 \\
\hline
\end{tabular}

Data recorded:

A. Vegetative growth: ten plants from each plot were chosen randomly after 120 days from transplanting for measuring the following characters: Plant height $(\mathrm{cm})$, Neck diameter $(\mathrm{cm})$ and Bulb yield $(\mathrm{cm})$.

B. yield components: including total yield, marketable yield and culls yield.

C. Bulb quality: including weight and diameter of bulbs.

Total soluble solids (T.S.S) were assayed according to A.O.A.C (1995).

D. Nutrient analysis: Bulb samples from every plot were chemically analyzed for N, P, K and B contents following standard methods (Chapman and Pratt, 1964).
The obtained data were subjected to the analysis of variance procedure and mean were compared using the L.S.D. method at $5 \%$ level of significance according to Gomez and Gomez (1984).

\section{Results and Discussion}

Significant effect of foliar application treatments was observed on vegetative growth in the $1^{\text {st }}$ and $2^{\text {nd }}$ seasons. This study indicates that foliar application treatments are required for achieving higher bulb yield of onion. The results are discussed under five crop headings:

1. Effects of foliar application treatments on vegetative growth (cm) of onion cultivar Giza 6 Mohassan: 
1.1 Plant height: Plant height was measured at 90 days after transplanting. There was a significant effect of treatments on the plant height of onion plant (Table 2). All treatments significantly increased plant height compared to the control (T1) in both seasons. The maximum plant height was obtained from application of yeast extract + Boron (T6). The increase percentage in plant height due to foliar application of T6 was (75.0\% and $76.46 \%)$ compared to the control (T1) in the $1^{\text {st }}$ and $2^{\text {nd }}$ seasons. Similar results were obtained by Ahmed et al., (2011) who found that increasing of foliar application of active dry yeast concentration up to $5 \mathrm{~g} / \mathrm{l}$ increased the vegetative growth characters of potato plants.

The positive effects of applying active dry yeast was attributed to its own contents of different nutrients, high percentage of protein, large amounts of vitamin B and natural plant growth regulators such as cytokinins (Glick, 1995; Fathy and Farid, 1996) or might be attributed to the role of sugar which needed to produce energy, promote growth, consequently affected plant growth (Filip Rolland et al., 2006).

1.2 Neck diameter: The highest bulb diameter $(2.57$ and $2.127 \mathrm{~cm})$ was observed in the T6 treatment (Yeast extract + Boron) and gave the maximum neck diameter compared to all other treatments (Table 2). The lowest neck diameter (1.323 and $1.353 \mathrm{~cm}$ ) was recorded in the $\mathrm{T} 1$ treatment (control) and statistically similar result was observed by the T3 (yeast) treatment. This result indicates a greater effect of B supplement over yeast extract which in turn influenced the neck diameter. Many authors reported that, the foliar application of yeast can enhance plant growth, fruit yield and improve its quality in cucumber. Yeast as a natural source of cytokinins-stimulates cell division and enlargement as well as the synthesis of protein, nucleic acid and chlorophyll (Fathy and Farid, 1996).

1.3 Bulb diameter: Bulb diameter varied from minimum values $(2.233$ and $2.257 \mathrm{~cm})$ recorded in foliar application with water (control) to maximum values (3.380 and 3.443 $\mathrm{cm})$ recorded in foliar application of amino acid + boron (T5) in the $1^{\text {st }}$ and $2^{\text {nd }}$ seasons, respectively (Table 2). All the treatments (T2-T6) showed significantly higher bulb diameter over the control (T1). The highest bulb diameter obtained from foliar application of amino acid + boron (T5) was 51.56\% and 52.54\% higher over control in the $1^{\text {st }}$ and $2^{\text {nd }}$ seasons, respectively (Fig.1). The results of the foliar application of amino acid + boron (T5) effect are carefully looked in to; it appears that the effect of B application was dominant over that of amino acid. Many studies have proved that, amino acids can directly or indirectly influenced the physiological activities of the plants (ElShabase et al., 2005, Awad et al., 2007; Al-Said and Kamal, 2008 and Faten et al., 2010). 
Table 2. Effect of foliar application on vegetative growth of onion cultivar Giza 6 Mohassan after 90 days from Transplanting

\begin{tabular}{|l|c|c|c|c|c|c|}
\hline \multirow{2}{*}{\multicolumn{1}{c|}{ Treatments }} & \multicolumn{6}{|c|}{ Vegetative growth (cm) } \\
\cline { 2 - 7 } & \multicolumn{2}{|c|}{ Plant height } & \multicolumn{2}{c|}{ Neck diameter } & \multicolumn{2}{c|}{ Bulb diameter } \\
\cline { 2 - 7 } & $\begin{array}{c}\mathbf{1}^{\text {st }} \\
\text { season }\end{array}$ & $\begin{array}{c}\mathbf{2}^{\text {nd }} \\
\text { season }\end{array}$ & $\begin{array}{c}\mathbf{1}^{\text {st }} \\
\text { season }\end{array}$ & $\begin{array}{c}\mathbf{2}^{\text {nd }} \\
\text { season }\end{array}$ & $\begin{array}{c}\mathbf{1}^{\text {st }} \\
\text { season }\end{array}$ & $\begin{array}{c}\mathbf{2}^{\text {nd }} \\
\text { season }\end{array}$ \\
\hline T1 (Control) & 53.85 & 55.25 & 1.323 & 1.353 & 2.233 & 2.257 \\
\hline T2 (Amino Acid) & 61.43 & 63.10 & 1.533 & 1.560 & 2.853 & 2.887 \\
\hline T3 (Yeast) & 76.10 & 78.02 & 1.770 & 1.820 & 2.317 & 2.457 \\
\hline T4 (Boron) & 62.37 & 65.35 & 1.490 & 1.510 & 2.523 & 2.547 \\
\hline T5 (Amino acid + Boron) & 73.32 & 75.40 & 1.730 & 1.813 & 3.380 & 3.443 \\
\hline T6 (Yeast + Boron) & 94.24 & 97.50 & 2.057 & 2.127 & 2.850 & 2.937 \\
\hline L.S.D. 0.05= & 2.58 & 2.34 & 0.12 & 0.14 & 0.16 & 0.13 \\
\hline
\end{tabular}

\section{Effects of foliar application} treatments on yield components of onion cultivar Giza 6 Mohassan:

Results of (Table 3 and Fig. 1) demonstrated the effect of foliar treatment on yield components.

2.1 Total yield (ton/fed.): All the treatments showed significantly higher bulb yield in comparison with the control (T1). Total yield (ton/fed.) varied from (15.35 and 16.01) recorded in foliar application of water (T1) (control) to (23.37 and 24.04) recorded in foliar application of Amino acid + Boron (T5) in the $1^{\text {st }}$ and $2^{\text {nd }}$ seasons, respectively (Table $3)$. The highest total yield was obtained from (T5) treatment $(52.24 \%$ and $50.15 \%$ ) higher than control (Fig.1).

\subsection{Marketable yield} (ton/fed.): The weight of marketable yield (ton/fed.) determined after harvest was significantly affected by the different treatments. The highest marketable yield (ton/fed.) (23.07 and 23.55 ton/fed.) was recorded from foliar treatment (T5). While, the lowest marketable yield (ton/fed.) (13.97 and 14.40) was recorded from (T1) treatment in the $1^{\text {st }}$ and $2^{\text {nd }}$ seasons, respectively. The increase percentage represented $(65.13 \%$ and $63.54 \%)$ compared to the control in the $1^{\text {st }}$ and $2^{\text {nd }}$ seasons, respectively.

2.3 Culls yield (ton/fed.): Culls yield (ton/fed.) was significantly affected by the different treatments. Foliar application of amino acid + Boron (T5) gave the most significant reduction in culls yield (ton/fed.) compared to the control (T1) and in comparison with all treatment under the study in the $1^{\text {st }}$ and $2^{\text {nd }}$ seasons, respectively. On the contrary, the maximum increase in Culls yield (ton/fed.) was obtained from foliar application with yeast extract (T3).

The positive results due to amino acid + Boron (T5) could attributed to the overall improvement in plant growth parameters and yield due to application of amino acids which may be due to providing readily source of growing substances which form the constitutes of protein in the living tissues. Generally, Amino acids were found to increase number of flowers, fruit setting and fruit yield (Neeraja et al., 2005). Results could be concluded that treating onion plants with foliar application of Amino acid + Boron (T5) gave the maximum total and marketable yield (ton/fed.) and had beneficial effects on reducing the culls yield (ton/fed.). 
The beneficial effects of amino acid + boron (T5) on yield components of onion may be due to boron spraying which is fundamental for the growth and development, acting as constituents of cell walls (B) and membranes
(B and $\mathrm{Zn}$ ), as constituents of enzymes ( $\mathrm{Fe}, \mathrm{Mn}, \mathrm{Cu}$ and $\mathrm{Ni}$ ), of activation of enzymes (Mn and $\mathrm{Zn}$ ) and in photosynthesis $(\mathrm{Fe}, \mathrm{Cu}, \mathrm{Mn}$ and Cl) (Kirkby and Römheld 2004; and Sharma 2006).

Table 3. Effect of foliar application on yield components of onion cultivar Giza 6 Mohassan

\begin{tabular}{|l|c|c|c|c|c|c|}
\hline \multirow{2}{*}{\multicolumn{1}{c|}{ Treatments }} & \multicolumn{6}{|c|}{ Yield components } \\
\cline { 2 - 7 } & $\begin{array}{c}\text { Total yield } \\
\text { (ton/fed.). }\end{array}$ & $\begin{array}{c}\text { Marketable } \\
\text { yield (ton/fed.). }\end{array}$ & \multicolumn{2}{c|}{$\begin{array}{c}\text { Culls yield } \\
\text { (ton/fed.). }\end{array}$} \\
\cline { 2 - 7 } & $\begin{array}{c}\mathbf{1}^{\text {st }} \\
\text { season }\end{array}$ & $\begin{array}{c}\mathbf{2}^{\text {nd }} \\
\text { season }\end{array}$ & $\begin{array}{c}\mathbf{1}^{\text {st }} \\
\text { season }\end{array}$ & $\begin{array}{c}\mathbf{2}^{\text {nd }} \\
\text { season }\end{array}$ & $\begin{array}{c}\mathbf{1}^{\text {st }} \\
\text { season }\end{array}$ & $\begin{array}{c}\mathbf{2}^{\text {nd }} \\
\text { season }\end{array}$ \\
\hline T1 (Control) & 15.35 & 16.01 & 13.97 & 14.40 & 1.373 & 1.613 \\
\hline T2 (Amino acid) & 18.23 & 19.02 & 17.58 & 17.67 & 0.993 & 1.350 \\
\hline T3 (Yeast) & 16.46 & 17.14 & 13.44 & 13.98 & 3.017 & 3.163 \\
\hline T4 (Boron) & 17.44 & 18.12 & 16.51 & 17.02 & 0.933 & 1.107 \\
\hline T5 (Amino acid +Boron) & 23.37 & 24.04 & 23.07 & 23.55 & 0.297 & 0.497 \\
\hline T6 (Yeast + Boron) & 18.59 & 19.27 & 16.80 & 17.23 & 1.787 & 2.037 \\
\hline L.S.D. 0.05= & 0.87 & 0.82 & 0.76 & 0.70 & 0.04 & 0.03 \\
\hline
\end{tabular}

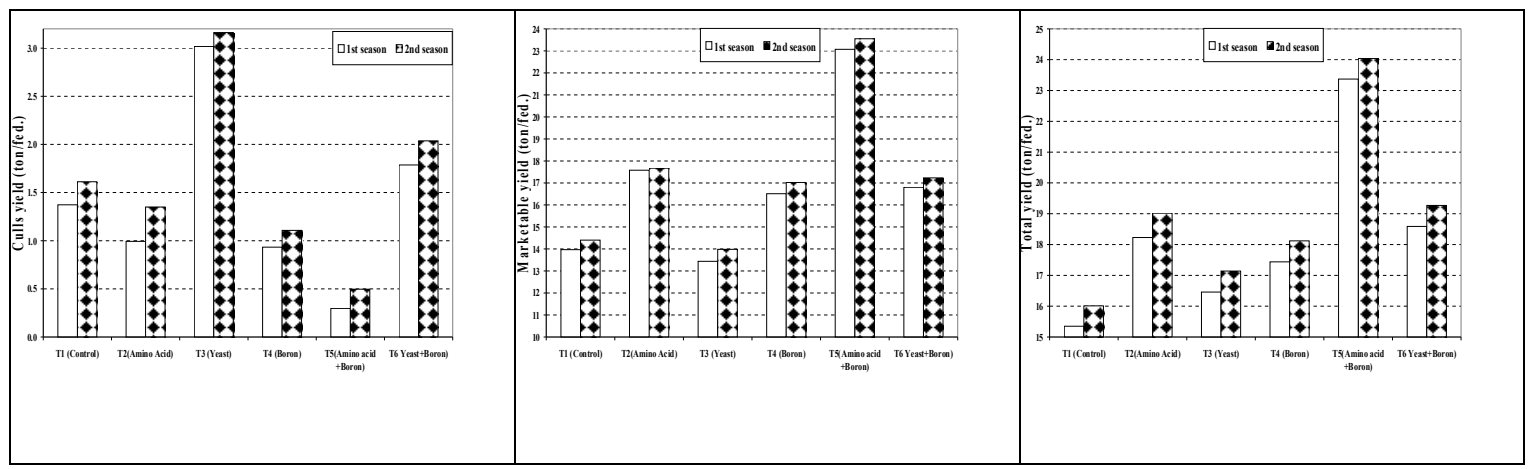

Fig. (1). Effect of foliar treatments on onion yield components of onion cultivar Giza 6 Mohassan

3. Effects of foliar application treatments on Bulb quality of onion cultivar Giza 6 Mohassan:

Data presented in Table (4) showed that all bulb quality significantly affected by foliar treatments. Foliar application of (amino acid + boron, T5) increased percentage of dry matter in bulbs (DM \% and total soluble solids (TSS) by $(274.34 \%$ and $298.38 \%)$ and $(37.89 \%$ and $37.93 \%)$ compered to control treatment (T1) in the $1^{\text {st }}$ and $2^{\text {nd }}$ seasons, respectively. Foliar treatment of (T5) tended to re- duce double bulbs, (\%) and bolting bulbs (\%) by $51.73 \%$ and $51.80 \%$ and $90.43 \%$ and $72.26 \%$ compared to the control (T1) in the $1^{\text {st }}$ and $2^{\text {nd }}$ seasons, respectively. Similar results was obtained by Tantawy, (2007) and ElAbagy et al., (2014) who found that mixture of amino acids proved to be effective in improving plant growth under abiotic stress hence it is expected to improve plant growth and production under normal environmental conditions. 
Table 4. Effects of foliar application treatments on Bulb quality of onion cultivar Giza 6 Mohassan

\begin{tabular}{|c|c|c|c|c|c|c|c|c|}
\hline \multirow{4}{*}{ Treatments } & \multicolumn{8}{|c|}{ Bulb quality } \\
\hline & \multicolumn{2}{|c|}{$\begin{array}{c}\text { Double bulbs } \\
(\%) .\end{array}$} & \multicolumn{2}{|c|}{$\begin{array}{l}\text { Dry matter } \\
\text { (DM (\%). }\end{array}$} & \multicolumn{2}{|c|}{$\begin{array}{l}\text { Total soluble sol- } \\
\text { ids (TSS). }\end{array}$} & \multicolumn{2}{|c|}{$\begin{array}{c}\text { Bolting bulbs } \\
(\%) .\end{array}$} \\
\hline & \multicolumn{8}{|c|}{ seasons } \\
\hline & $1^{\text {st }}$ & $2^{\text {nd }}$ & $1^{\text {st }}$ & $2^{\text {nd }}$ & $1^{\text {st }}$ & $2^{\text {nd }}$ & $1^{\text {st }}$ & $2^{\text {nd }}$ \\
\hline T1 (Control) & 4.627 & 4.807 & 11.50 & 11.89 & 11.613 & 12.117 & 1.390 & 1.453 \\
\hline T2 (Amino acid) & 2.500 & 2.767 & 25.40 & 25.96 & 14.550 & 14.907 & 0.543 & 0.650 \\
\hline T3 (Yeast) & 4.840 & 5.170 & 15.84 & 16.10 & 12.340 & 12.933 & 1.497 & 1.640 \\
\hline T4 (Boron) & 3.123 & 3.250 & 21.70 & 22.25 & 12.157 & 13.287 & 0.780 & 0.790 \\
\hline T5 (Amino acid + Boron) & 2.233 & 2.317 & 43.05 & 43.92 & 16.010 & 16.713 & 0.133 & 0.403 \\
\hline T6 (Yeast + Boron) & 3.213 & 3.433 & 26.78 & 27.30 & 13.583 & 14.247 & 0.867 & 0.927 \\
\hline L.S.D. 0.05 & 0.06 & 0.08 & 2.13 & 2.65 & 0.26 & 0.28 & 0.012 & 0.016 \\
\hline
\end{tabular}

4. Effects of foliar application treatments on nutrient concentration of onion cultivar Giza 6 Mohassan after 60, 120 and 180 days from storing:

Effects of foliar treatments revealed varied response of the nutrient concentration to foliar treatments (Table $\overline{\overline{5}}$ 5). The maximum nutrient concentration under the study was obtained from foliar application of (amino acid + boron, T5) in both seasons. N, P and $\mathrm{K}$ concentration strongly responded to the foliar application of (T5), while, boron concentration of onion bulbs responded to foliar application of boron (T4) followed by (T5). It's known that the critical level of boron in crops ranges from 5 to $10 \mu \mathrm{g} \mathrm{g}^{-1}$ for monocots and 20 to $70 \mu \mathrm{g} \mathrm{g}^{-1}$ for dicots (Mortvedt, 1991). Tariq and Mott (2007) concluded the critical boron deficiency and toxicity levels that for most cru- ciferous and root crops the concentration of boron in plants $<15 \mu \mathrm{g} \mathrm{g}^{-1}$ to be deficient, $25-100 \mu \mathrm{g} \mathrm{g}^{-1}$ adequate and $>200 \mu \mathrm{g} \mathrm{g}^{-1}$ toxic for growth and production. It is clear that both boron deficiency and toxicity will result in reduction of crop yield and quality

This superiority of (T5) might be due to beneficial effects of foliar application of amino acid which enhance plant growth, fruit yield and improve its quality in cucumber (Kandil et al., 2013). Boron play great role in carbohydrate metabolism and transport of sugars (Katyal and Randhawa, 1983), phenol and auxin metabolism (Mengel and Kirkby, 1982), water relations (Sharma and Ramchandra (1990), tissue development, differentiation and formation of cell walls (Katyal and Randhawa, 1983), and reproduction and germination of pollen and disease resistance (Bergmann, 1984). 
Table 5. Effect of foliar application on $\mathrm{N}, \mathrm{P}$ and $\mathrm{K}$ and $\mathrm{B}$ concentration in onion bulb of cultivar Giza 6 Mohassan

\begin{tabular}{|c|c|c|c|c|c|c|c|c|}
\hline \multirow{4}{*}{ Treatments } & \multicolumn{8}{|c|}{ Onion bulb concentration } \\
\hline & \multicolumn{2}{|c|}{$\begin{array}{l}\mathrm{N} \\
\%\end{array}$} & \multicolumn{2}{|c|}{$\begin{array}{l}\mathbf{P} \\
\%\end{array}$} & \multicolumn{2}{|c|}{$\begin{array}{l}\mathbf{K} \\
\%\end{array}$} & \multicolumn{2}{|c|}{$\begin{array}{c}\text { B } \\
\text { ppm }\end{array}$} \\
\hline & \multicolumn{8}{|c|}{ Seasons } \\
\hline & $1^{\text {st }}$ & $2^{\text {nd }}$ & $1^{\text {st }}$ & $2^{\text {nd }}$ & $1^{\text {st }}$ & $2^{\text {nd }}$ & $1^{\text {st }}$ & $2^{\text {nd }}$ \\
\hline T1 (Control) & 1.660 & 1.680 & 0.150 & 0.151 & 1.833 & 2.072 & 18.613 & 18.873 \\
\hline T2 (Amino acid) & 1.710 & 1.730 & 0.167 & 0.168 & 1.970 & 2.226 & 19.573 & 19.860 \\
\hline T3 (Yeast) & 1.770 & 1.790 & 0.197 & 0.198 & 2.047 & 2.313 & 19.817 & 20.110 \\
\hline T4 (Boron) & 1.600 & 1.620 & 0.187 & 0.188 & 2.163 & 2.445 & 20.067 & 20.370 \\
\hline T5 (Amino acid +Boron) & 1.810 & 1.830 & 0.203 & 0.205 & 2.083 & 2.354 & 19.797 & 20.090 \\
\hline T6 (Yeast + Boron) & 1.800 & 1.810 & 0.193 & 0.195 & 1.923 & 2.173 & 19.343 & 19.623 \\
\hline L.S.D. 0.05 $=$ & 0.26 & 0.21 & 0.04 & 0.03 & 0.13 & 0.18 & 0.32 & 0.24 \\
\hline
\end{tabular}

5. Effects of foliar application treatments on total weight loss $(\%)$ of onion bulb of Giza 6 Mohassan after 60, 120 and 180 days from storing:

The percentage of weight loss was steadily increased until 180 days of storage (Fig. 1). Data in Table (6) show that weight losses of onion (\%) significantly affected by all treatments under the study. Foliar application of yeast extract (T3) gave the maximum weight losses of onion $(\%)$ in both seasons. Boron treatment (T4) had the most pronounced effect on bulb weight loss during storage, compared to the control and other treatments. All other treatments showed higher percentage of weight loss com- pared to the control during all storage times. Concerning shrinking percentage, it was noticed that plants sprayed with either boron (T4) or amino acid (T2) had better storability of bulbs than other treatments and the control. These results may be due to the effect of boron and amino acid on growth parameters which may reflect on enhancing the quality and storability of onion bulbs. In this regard, Bardisi (2004) found that high quality of garlic bulbs was obtained during 300 days of storage when plants were sprayed with bio-stimulants (ascorbic acid.). Ahmed et al. (2010) stated that plants sprayed with humic acid had better storability than untreated ones.

Table 6. Effect of foliar application treatments on total weight loss (\%) of Giza 6 Mohassan onion bulb during storage period.

\begin{tabular}{|l|c|c|c|c|c|c|}
\hline \multirow{2}{*}{ Treatments } & \multicolumn{6}{|c|}{ Days after storage time } \\
\cline { 2 - 7 } & \multicolumn{2}{|c}{$\mathbf{6 0}$} & \multicolumn{7}{c|}{$\mathbf{1 2 0}$} & \multicolumn{2}{c|}{$\mathbf{1 8 0}$} \\
\cline { 2 - 7 } & \multicolumn{7}{|c|}{ Seasons } \\
\cline { 2 - 7 } & $\mathbf{1}^{\text {st }}$ & $\mathbf{2}^{\text {nd }}$ & $\mathbf{1}^{\text {st }}$ & $\mathbf{2}^{\text {nd }}$ & $\mathbf{1}^{\text {st }}$ & $\mathbf{2}^{\text {nd }}$ \\
\hline T1 (Control) & 0.327 & 0.190 & 0.567 & 0.433 & 0.603 & 0.490 \\
\hline T2 (Amino acid) & 0.380 & 0.280 & 0.597 & 0.483 & 0.640 & 0.563 \\
\hline T3 (Yeast) & 0.467 & 0.303 & 0.643 & 0.520 & 0.707 & 0.640 \\
\hline T4 (Boron) & 0.270 & 0.150 & 0.503 & 0.403 & 0.510 & 0.447 \\
\hline T5 (Amino acid + Boron) & 0.330 & 0.203 & 0.540 & 0.440 & 0.583 & 0.523 \\
\hline T6 (Yeast + Boron) & 0.407 & 0.253 & 0.573 & 0.477 & 0.630 & 0.570 \\
\hline L.S.D. 0.05= & 0.04 & 0.03 & 0.02 & 0.03 & 0.04 & 0.03 \\
\hline
\end{tabular}

\section{References}

A.O.A.C. (1995). Official Method of Analysis, $16^{\text {th }}$ Ed., Association of
Official Analytical Chem-ists International, Arlington Virginia, USA. 
Agricultural Export Council data, (2017).

https://www.freshplaza.com/article /2192775/egypt-golden-onionsavailable-for-export/.

Ahmed, MEM, El-Aidy AA, Radwan EA, Abd El-Bary TS (2010). Response of garlic plants to humic acid and different application methods of potassium fertilizer. Minufiya J Agric Res. 35 (6): 2159-2175.

Ahmed, A.A., M.M.H. Abd El-Baky, M.F. Zaki and Faten S. Abd El-Aal (2011). Effect of Foliar Application of Active Yeast Extract and Zinc on Growth, Yield and Quality of Potato Plant (Solanum tuberosum L.) Journal of Applied Sciences Research, 7(12): 2479-2488, 2011.

Al-Said, M. A., \& Kamal, A. M. (2008). Effect of foliar spray with folic acid and some amino acids on flowering, yield and quality of sweet pepper. J. Agri. Sci., Mansoura Univ., 33(10), 7403-7412.

Awad, El-M. M., Abd El-Hameed, A. M., \& El-Aimin, Z. A. (2007). Effect of Glycine, Lysine and nitrogen fertilizer rates on growth, yield and chemical composition of potato. J. Agric. Sci. Mansoura Univ., 32(10), 8541-8551.

Bardisi, A. (2004). Influence of vitamin $\mathrm{C}$ and salicylic acid foliar application on garlic plants under sandy soil conditions. II. Yield and storability. Zagazig J Agric Res. 31 (4A): 1349-1360.

Bergmann, W., (1984). The significance of the micronutrient boron in agriculture. Proceedings of the Symposium held by the borax group in the International Trade Centre of GDR, December 20, 1984, Berlin.

Castelfranco, P.A. and S.I. Beale, (1983). Chlorophyll biosynthesis recent advances and areas of cur- rent increst. Ann. Rev. Plant Physio., 34: 241-278.

Chapman, CA, Pratt PF (1964). Methods of Analysis for Soil, Plant and Water. Div. Agric. Sci., University of California, USA. Agricultural Export Council data, (2017) https://www.freshplaza.com/article /2192775/egypt-golden-onionsavailable-for-export/.

El-Abagy, H.M., W.A. El-Tohamy, A.M.R. Abdel-Mawgoud and S.D. bou-hussein (2014). Effect of Different Amino Acid Sources and Application ates on Yield and Quality of Onion in the Newly Reclaimed Lands. Middle East Journal of Agriculture Research, 3(1): 81-88.

El-Shabasi, M.S., Mohamed, S.M, \& Mahfouz, S.A. (2005). Effect of foliar spray with some amino acids on growth, yield and chemical composition of garlic plants. The $6^{\text {th }}$ Arabian Conf. for Hort., Ismailia, Egypt.

Faten, S. Abd El-Aal, Shaheen, A.M., Ahmed, A.A., \& Asmaa, R. M. (2010). The effect of foliar application of urea and amino acids mixtures as antioxidants on the growth and yield and characteristics of squash. Res. J. Agric. Biol. Sci., 6(5), 583-588.

Fathy and Farid, (1996). The possibility of using vitamin Bs and yeast to delay senescence and improve growth and yield of common beans (Phaseolus vulgaris L.). J Agric Sci Mansoura Univ. 21 (4): 14151423.

Filip Rolland; Elena Baena-Conzalelz and Jen Sheen (2006). Annals Review of Plant Biology. Volume, 57, Page, 675 - 209.

Glick, B.R., (1995). The enhancement of plant growth by free living bacteria. Cand. J. Microbiology, 41: 109-117. 
Gomez, K.A. and A.A. Gomez, (1984). Statistical procedures for agricultural research (2 ed.). John wiley and sons, New York, 680p.

Jackson, M.L, (1962). Soil Chemical Analysis, (Prentice Hall, Inc. Eaglewood Cliffs, N.Y. pp 219221).

Kandil, A., Ali E. Sharief, Fathalla H. Fathalla (2013). Onion yield as affected by foliar application with amino and gunic acids under nitrogen fertilizer levels. ESci J. Crop Prod. 02 (02) 2013. 62-72.

Katyal, J.C. and N.S. Randhawa, (1983). Micronutrients. Food and Agriculture Organization, United Nations.

Kirkby, E.A., V. Römheld, (2004). Micronutrients in plant physiology: functions, uptake and mobility. Proceedings No. 543, International Fertiliser Society.

Mengel, K. and E.A. Kirkby, (1982). Principles of Plant Nutrition. $3^{\text {rd }}$ Edn., International Potash Institute, Worblaufen-Ben/ Switzerland, pp: 593-655.

Mortvedt, JJ (1991). Micronutrient fertilizer technology. In: J. J. Mortvedt, F. R. Cox, L.M. Shuman and R.M. Welch (Eds.), Micronutrients in Agriculture. Soil Sci. Soc. Amer., Mad., WI, pp. 523-548. Yoshida S, Fomo AD, Cock JA, Gomez KA (1976). Physiological Studies of Rice. International Rice Research Institute, Manila, Philippines.

Neeraja, G., I.P. Reddy, B. Gautham, (2005). Effect of growth promoters on growth and yield of tomato cv. Marutham. Journal of Research ANGRAU., 33(3): 68-70.

Sarojnee, D.Y., B. Navindra and S. Chandrabose, (2009). Effect of naturally occurring amino acid stimulants on the growth and yield of hot peppers (Capsicum annum L.). Journal of Animal \& Plant Sciences, 5(1): 414-424.

Sharma, C.P., (2006). Plant micronutrients. Part I, Science Publisher, USA, pp: 272.

Sharma, P.N. and T. Ramchandra, (1990). Water relations and photosynthesis in mustard plants subject to boron deficiency. Indian J. Plant Physiol., 33: 150-154.

Tantawy, A., (2007). Effect of some mineral and organic compounds on salinity tolerance in tomato. Ph.D. thesis. Fac. Agric. Al Azhar Univ.

Tariq, M. and C.J.B. Mott (2007). The Significance of Boron in Plant Nutrition and Environment-A Review. Journal of Agronomy. Volume 6 (1): 1-10.

Tugnoli, V. \& G. Bettini. (2003). The use of foliar fertilizer application in sugar beet growing. $1^{\text {st }}$ Joint IIRB-ASSBT Congress, $26^{\text {th }} \mathrm{Feb}$ $1^{\text {st }}$ March 2003, San.

Wills, R.H.; T.H. Lee; D. Gerham; W.B. McGlasson and E.G. Hall (1982). Postharvest and introduction to physiology and handing of fruit and vegetables. The AVF Publishing Comp. Inc. Westport. Conn. pp. 35. 
استجابة محصول البصل للرش الورقي بالأحماض الأمينية ومستخلص الخميرة والبورون في

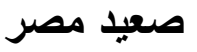

جمال حسين عبد الرحيم'، عبد المنعم عباس جامع '، محمد سليمان سليمان البسيوني'

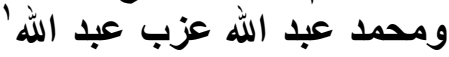

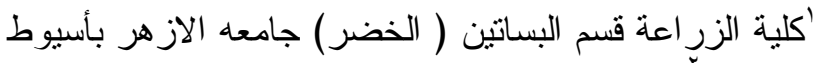

$$
\begin{aligned}
& \text { "مركز البحوث الزر اعية قسم بحوث البصل الإنه }
\end{aligned}
$$

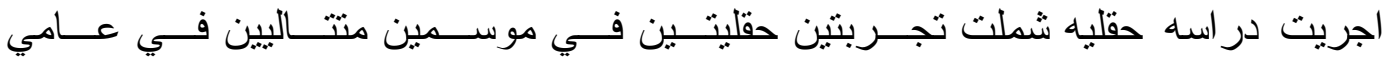

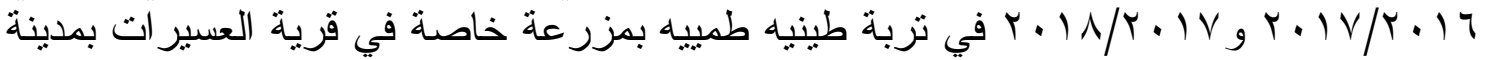

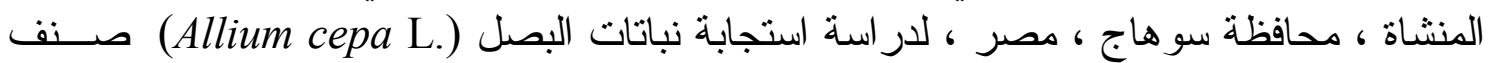

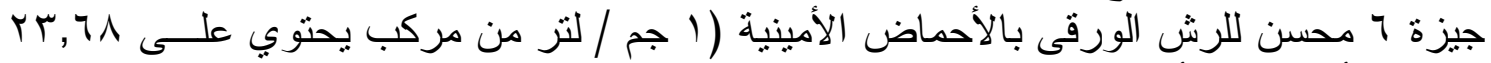

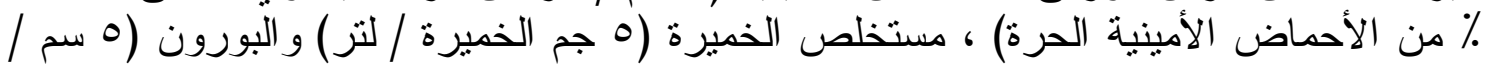

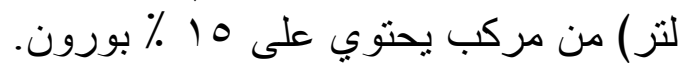

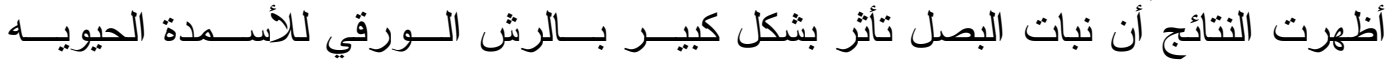

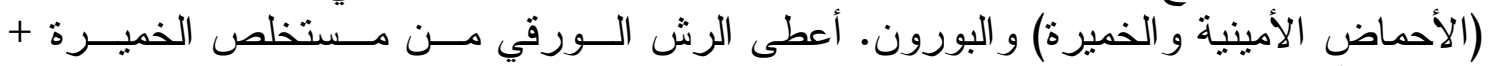

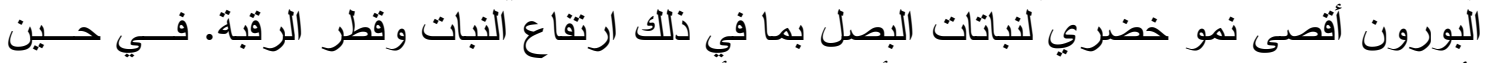
تأثر محصول البصل بالرش الورقي للأحماض الأمينية + البورون.

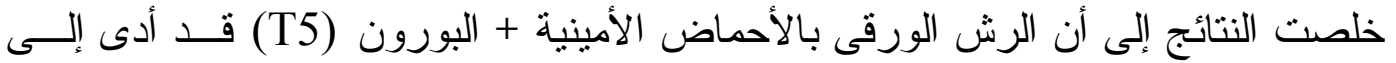

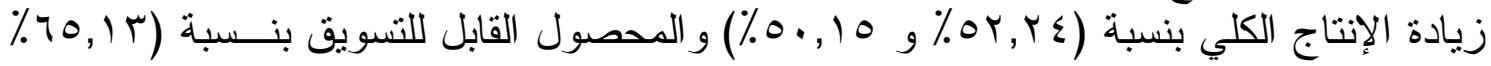

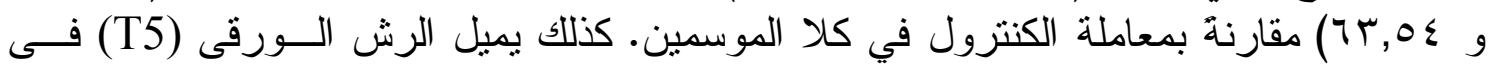

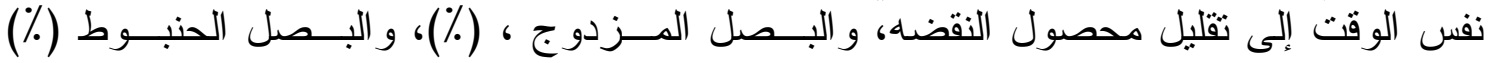

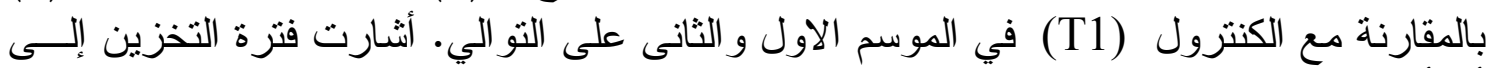

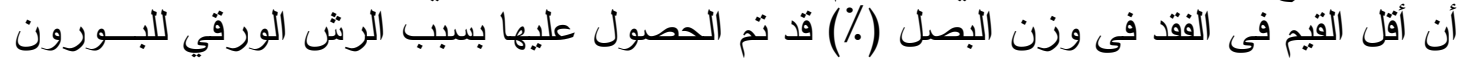

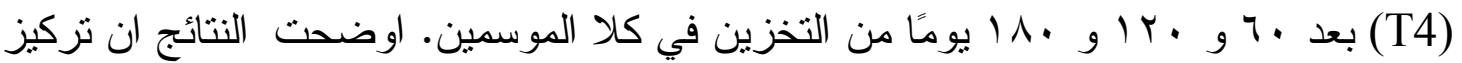

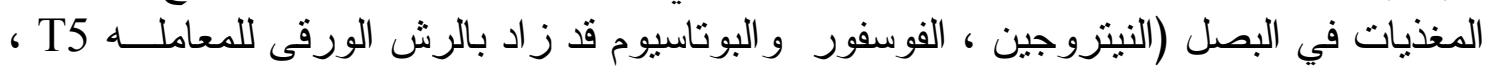

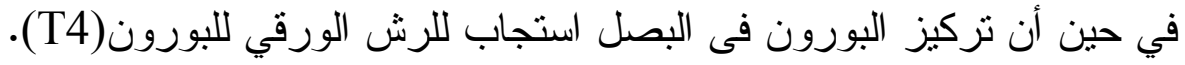

